\title{
IDEAS \& Application and validation of a GIS-based stream INNOVATIONS bank stability tool for the Great Lakes region
}

\author{
Amanda G. Stone, Mark S. Riedel, Travis Dahl, and James Selegean
}

W atershed sediment contributions are a continual source of pollution to the Great Lakes. Sediment from upstream sources may deliver contaminants such as polychlorinated biphenyls (PCBs) and excess nutrients such as phosphorus to the lakes. The excess nutrients often contribute to algal blooms and degradation of freshwater habitat.

The sediment loading from agricultural watersheds is often aggravated by ditch maintenance activities. Many of the agricultural lands draining into the Great Lakes lie on lacustrine clay and till plains and consequently have very little relief, resulting in poor drainage. Tile drains and ditches are often constructed in these areas to accelerate drainage and facilitate utilization of land for agriculture. Ditch maintenance activities include removal of riparian vegetation and dredging to increase conveyance.

Section 516(e) of the Water Resources Development Act of 1996 directed the US Army Corps of Engineers (USACE) to develop sediment transport models for major Great Lakes tributaries contributing sediment to federal navigation projects (harbors, channels, etc.) or Areas of Concern (AOCs). Under this legislation, the models are developed to assist watershed stakeholders with the development of watershed management approaches to soil conservation and sediment management to reduce sediment loads, dredging costs, and the need for other sediment-based remediation activities. As part of the Sebewaing River Watershed 516(e) project, we developed the Channel Stability Tool (CST) to help watershed stakeholders in the decision making process for agricultural drain maintenance by allowing them to determine how maintenance practices would

Amanda Stone is a water resources specialist and Mark Riedel is the senior hydrologist with W.F. Baird and Associates, Ltd, Madison, Wisconsin. Travis Dahl and James Selegean are hydraulic engineers with the Detroit District of the US Army Corps of Engineers, Detroit, Michigan. affect stability and where and what types of vegetation can be planted in the riparian system to help stabilize stream banks and reduce potential sediment loading to their federal harbor.

\section{MATERIALS AND METHODS}

Study Location. The 26,709 ha (66,000 ac) Sebewaing River Watershed is located on the shore of Saginaw Bay, Lake Huron, on the "thumb" of East Central Michigan.The watershed is rural with a few small villages and the town of Sebewaing. Land cover is over $90 \%$ agricultural with the majority of farms operating a rotation of corn and sugar beets, relying on an extensive artificial drainage network that consists of the Sebewaing River and a network of over $240 \mathrm{~km}(150 \mathrm{mi})$ of agricultural drains, the largest of which are the State and Columbia drains. The confluence of this network of drains ends at Sebewaing Harbor, Sebewaing, Michigan, on Saginaw Bay. The configuration of the outlet at Saginaw Bay is such that Sebewaing Harbor acts as a large sediment trap for the sediments arriving from upstream source, where ice dams often cause significant village flooding. The USACE Detroit District dredges the harbor periodically (most recently in 2008) to remove built-up sediments for maintenance of recreational boating and navigation (Schwartz 2006).

Erosion and instability of ditches is widespread in the Sebewaing watershed and includes bank failure, bank scour, and bed incision (scour). These pose significant challenges with ditch maintenance, loss of cropland, and undermining of bridge piers and footings. While considerable efforts have been undertaken to reduce other sources of watershed sedimentation, little has been done to address fluvial sources (Schwartz 2006; USDA 2004; FTC\&H 2001, 2004).

Maintenance is frequently conducted on these drainage networks to "increase conveyance," including vegetation removal and dredging. These ditch maintenance activities sometimes cause over-steepening of the banks and excessive exposure of bank soils, making them vulnerable to erosion and bank failure and resulting in increased fluvial sediment loads to Sebewaing Harbor. Figure 1 is an example of a typical channel within the Sebewaing watershed that is experiencing bank failure and bed scour, the causes of which have not been previously investigated.

Geology of Study Area. Quaternary glacial deposits dominate the surficial geology of the area, which includes widespread deposits of cohesive clay-dominated till and lacustrine clay plains throughout the Great Lakes region (figure 2). Natural clay channel streams in this setting can be quite resilient because clay dramatically increases the cohesive strength of soils, stream banks, and channel resistance to scour (Riedel et al. 2006; Schumm 1960).

In clay channel streams draining to Lake Superior, bank and channel stability are strongly influenced by watershed and riparian land use practices (Riedel et al. 2005, 2006). Conversion of natural riparian land use to agricultural practices typically reduces the stability of stream banks (Abernethy and Rutherfurd 2001; Millar 2000; Hupp 1992, 1999; Charlton et al. 1978) and can cause dramatic morphologic response (Riedel et al. 2006; Osman and Thorne 1988; Huang and Nanson 1998).

Stream Channel Stability Tool Development. The Channel Stability Tool (CST) was developed to provide a simple method for watershed stakeholders to assess the impact of different management practices on channel stability. With a combination of hydraulic and geotechnical analyses, the CST addresses the three main components of channel stability:

- Stream bed stability and resistance to scour (incision)

- Stream bank resistance to scour (bank erosion or retreat)

- Stream bank stability (bank resistance to gravitational failure or slumping)

The scientific basis of the CST was originally developed using a combination of field studies, mechanistic, and empirical analyses of clay channel streams 


\section{Figure 1}

Example of channel exhibiting bank failure within the Sebewaing River watershed, Saginaw Bay, Lake Huron, East Central Michigan.

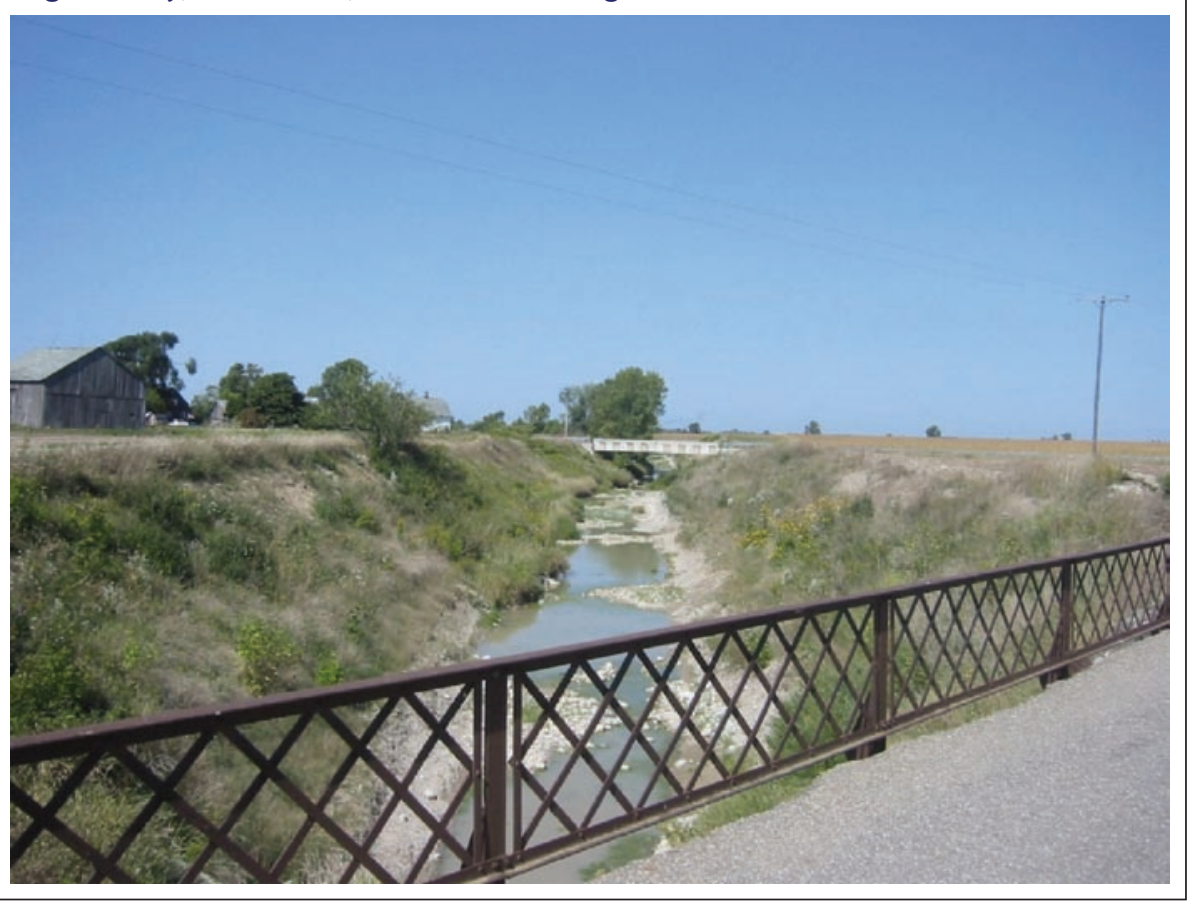

\section{Figure 2}

Quaternary lacustrine clay and clay till deposits in the Great Lakes region (with data from Soller and Packard 1998).

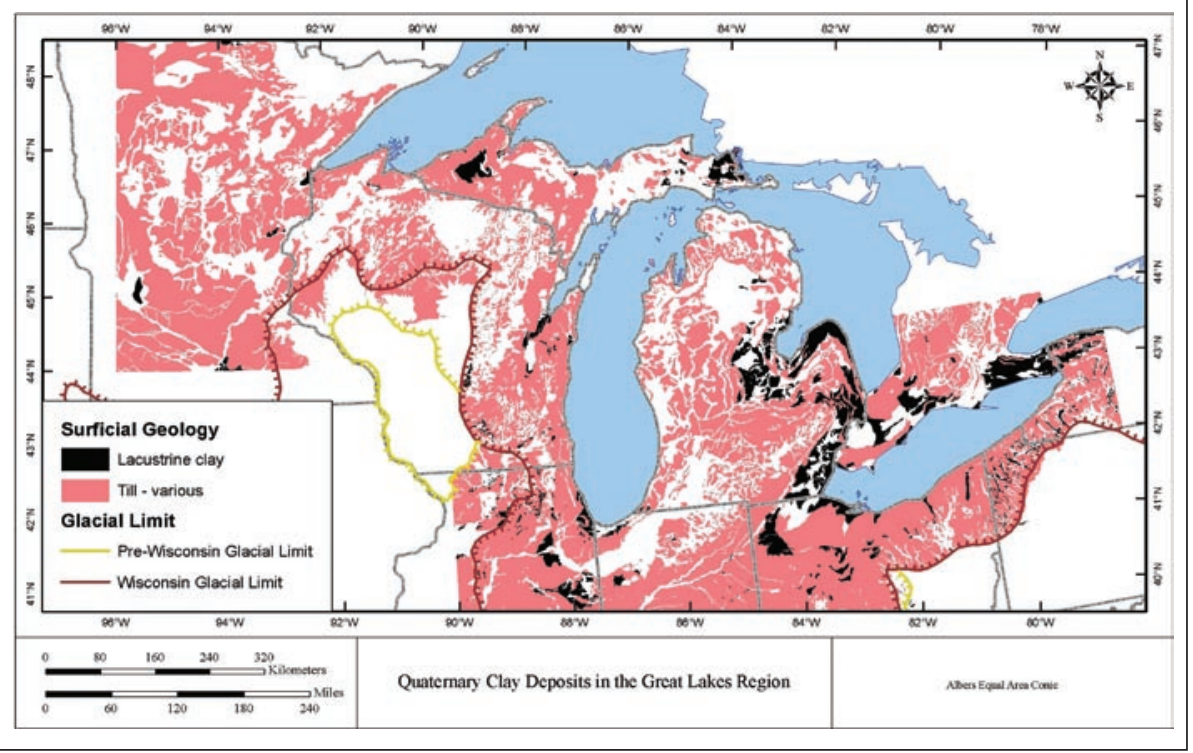

draining the lacustrine clay beds of glacial lakes Duluth and Nemadji in East Central Minnesota (Riedel et al. 2002, 2006). The CST provides full analyses of driving variables that impact stream bank stability, including bed slope, bank slope, bank vegetation type (over-story and under-story), bank vegetation density, soil characteristics, and stage and discharge data. The CST does not consider potential changes in the two primary driving variables that influence the origin and natural evolution of fluvial systems - water and sediment load. These variables are dictated by watershed climate, geology, and land use. Rather, the CST considers changes in secondary, local (riparian) variables that influence stability. This approach is warranted when watershed conditions have not changed significantly. For example, agricultural land cover and ditches were established in the Sebewaing watershed over 100 years ago. There have been no significant changes in ditch density or agricultural land practices over the past 30+ years. Given watershed hydrology and sediment sources have been stable, the CST addresses changes in variables of the fluvial system to assess the bank stability and bed and bank erosion susceptibility at different locations throughout the watershed. The CST uses these remaining variables from user input and built-in databases to carryout geotechnical computations and predicts the factors of safety (F.S.) for the three different components of channel stability.

Interface. The CST is a simple geographical information system (GIS) based user interface within the ArcGIS environment that was developed using ArcObjects (Environmental Systems Research Institute, ArcGIS, Version 9.1) and Visual Basic programming languages. The reader is directed to Riedel et al. (2006) for a comprehensive description of the data development and theory for the CST and to the Sebewaing River Watershed Sediment Transport Report for a full user manual with example applications and sample data (USACE 2007).

The CST interface guides the user through a seven-step process using a combination of user input and data from built-in databases to complete stability calculations. The first two steps query field-surveyed geometry data from GIS files and calculate channel hydraulic variables. Geotechnical properties of the banks are calculated from soil bulk density and cohesive strength (either entered directly or calculated from soil clay content with typical values for the region provided). Critical shear stress values for soils of the Great Lakes are available in pull-down menus or can be entered manually. Vegetation type and cover for each bank can be selected from a built-in database of root tensile strength data for woody and herbaceous vegetation (see figure 3). With each step in the CST, the user 


\section{Figure 3}

Example illustrating step 4 from the application scenarios (woody vegetation metrics) in the CST interface within ArcGIS.

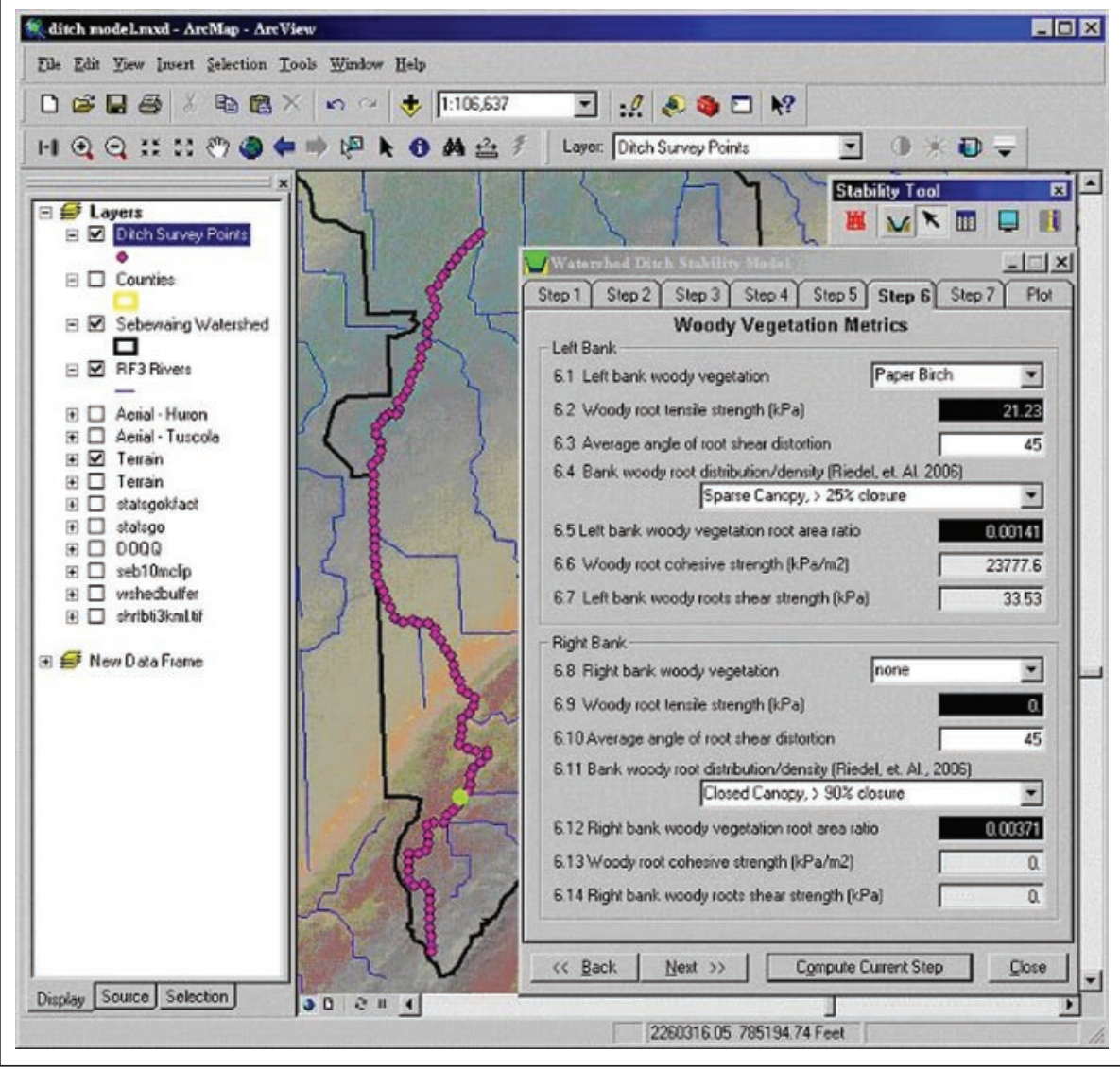

can manually override data to simulate alternative channel condition scenarios and estimate resultant impacts on stability. The results tab displays the results of F.S. for bank scour, bank stability, and bed scour. Results are displayed in color-coded format to indicate stable (green), unstable (red), or the threshold range of (in)stability (yellow). Results can be saved to a .dbf file that can be viewed (as tabular data or channel cross section) within the CST and exported for use with other software. Channel cross sections can also be plotted within the CST.

Analytical Approach. The CST is a mechanistically based model that predicts stability as F.S. for various modes of failure using geotechnical and hydraulic analyses (resisting forces versus failure forces). Published methods for geotechnical stability analysis and computations for the F.S. in fluvial studies are well documented and provide guidance for their implementation (ASCE 1998; Osman and Thorne
1988; Darby and Thorne 1996). Given inherent uncertainties in quantifying stability, a F.S. equal to 1 does not indicate a point of incipient failure or instability/stability threshold. Rather, a range of values is typically used; the CST employs a range of less than 0.8 as unstable (red), greater than 1.2 as stable (green), and 0.8 to 1.2 as the threshold of (in)stability (yellow).

The mechanistic equations of the CST were originally calibrated and validated against field observations and empirical measures of stability in a range of riparian land-use conditions, including natural forest, various levels of grazing pressure, and agricultural lands in Minnesota (Riedel et al. 2006). Independent testing was conducted to verify proper design and implementation of the CST, and independent engineers at the USACE Detroit District completed the final review.

Bed and Bank Resistance to Scour. Crosssectional average shear stress is computed as the depth-slope product. Partitioning of shear stress between the streambeds and banks is computed using the empirical relationship of shear stress for trapezoidal channels (Knight et al. 1984; Flintham and Carling 1988) and validated against published data (ASCE 1998; Ritter et al. 1995; Schumm 1960). Critical shear stress for the cohesive lacustrine clay was estimated based upon soil water chemistry using published data from the US Environmental Protection Agency (Arulanandan et al. 1980; Bahnick et al. 1979) and Chow's unit tractive force relationship for cohesive soils (Chow 1959). The CST calculates bed and bank scour assuming bare soils, independent of the riparian vegetation impacts on bank stability. Consequently, if the channel is vegetated, the CST will underestimate stability with respect to scour because it cannot account for vegetative shielding of soils from shear stress.

Bank Stability. The CST provides a critical failure analysis where banks would be most likely to fail-saturated banks following the passage of hydrograph peak storm event. In this situation, banks have maximum weight, positive pore pressure that is not offset by high water levels in the channel, and bank toes may be eroded, leaving banks most susceptible to failure (Alabyan and Chalov 1998; Chang 1979; Hickin 1995; Huang 1983; Leopold et al. 1992). Bank strength is estimated using an adaptation of the Mohr-Coulomb equation that includes the contribution of root tensile strength and soil cohesive strength following the fiber-reinforced matrix model (adapted from Millar and Quick 1998; Taylor 1948). A database of root tensile strengths was developed from published literature and publicly available sources and includes large datasets of plant species common in the clay soils of the Great Lakes region (Kaputska and Davidson 1979). This root tensile strength was partitioned across unit area of soil using Wu's (1976) theoretical model of a fiber-reinforced soil to determine the root contribution to stability of each bank.

Validation and Application. The CST was applied to a random selection of 10 ditch cross sections on the State drain for validation and to examine the effect that management practices would have on channel stability and contribution of sedi- 
ment to downstream reaches. The results from the CST examine the F.S. for bank stability on both the left and right banks in addition to the F.S. against scour on the bed and banks.

The applications presented illustrate how the CST can be used by watershed stakeholders to make informed watershed management decisions. For example, stakeholders can use the CST to determine what vegetative cover type works best at specified locations depending on typical flow scenarios. If one location is prone to full-channel flow due to channel geometry or obstructions, this can be specified within the CST. The effects of channel geometry adjustments, such as dredging, can also be tested to prevent inadvertent destabilization of stable channels.

Validation and Application Scenarios. Two validation scenarios were conducted by comparing results for different flow levels to current conditions and channel metrics as measured from crosssectional surveys conducted during recent ditch maintenance activities (Williams, Osminski, \& Associates 2002), high-resolution aerial photographs from the Farm Service Agency, and field reconnaissance. General soil information was obtained from soil survey data, and vegetation type and density were estimated from field investigations and aerial photographs.

1.Pre-dredging versus post-dredging (validation)—Channel dimensions from pre-dredging conditions and post-dredging conditions were compared. Flow in the channels was simulated at bankfull since most excavation had occurred within the bankfull channel. Channels were 100\% vegetated with a perennial ryegrass (Lolium perenne L.) cover.

2. Half-full channel versus full channel (validation)-Flow conditions with half-full, dredged channels were compared to full-flow, dredged channels. Channel vegetation was $100 \%$ ryegrass cover. These high flow conditions commonly occur during the snowmelt season when ice dams cause flooding.

Application scenarios represent common ditch management, vegetation cover, and flow conditions that are currently in practice or could be applied with different management practices. For the purposes of simplicity, these scenarios represent situations where both banks have the same soil and vegetation conditions; however, the CST provides independent conditions for left and right banks. These scenarios represent a sample of the numerous scenarios that could be tested:

1. Bare banks versus perennial ryegrass cover-Completely bare banks were compared with 100\% perennial ryegrass covered banks. Channels were post-dredging geometry with fullchannel flows.

2. Riparian shrub cover-A shrub cover consisting of $50 \%$ beaked hazel (Corylus cornuta) and $50 \%$ perennial ryegrass was compared to $100 \%$ perennial ryegrass covered banks. Channels were postdredging geometry with full-channel flows.

3. Coniferous forest-A $100 \%$ canopy white pine forest riparian cover was compared to $100 \%$ perennial ryegrass cover. Channels were post-dredging geometry with full-channel flows.

4. Deciduous forest-A 100\% paper birch forest riparian cover was compared to $100 \%$ perennial ryegrass cover. Channels were post-dredging geometry with full-channel flows.

\section{RESULTS AND DISCUSSION}

The CST was applied to 10 cross-section locations for 2 validation and 4 application scenarios. Box and whisker plots illustrate the results of the tests on the 10 cross sections for each condition tested; the minimum, first quartile, median, third quartile, and maximum of the data served as the box and whiskers (figure 4). The range for the threshold of (in)stability $(0.8$ to 1.2$)$ is depicted in this figure by lines labeling the "stable" and "unstable" threshold regions.

A qualitative validation of the CST was done by comparing CST results to field observations. Variation within each scenario was due to inherent differences in the location of the cross sections, such as bed slope, catchment area, and degree of channelization.

The pre-dredging and post-dredging bankfull conditions (validation scenario 1 , figures $4 \mathrm{a}$ and $4 \mathrm{~b}$ ) were stable against bank failure, bank scour, and bed scour for all cross sections tested because of the limited nature of dredging. However, dredging impacts on channel stability with respect to scour would be significant if banks are allowed to remain bare.

The higher flow conditions (validation scenario 2), including both half-full and full channels, produced anticipated results with significantly greater bank instability and scour potential as compared to the bankfull scenarios (see figures $4 c$ and 4d). This was observed in areas within the drainage basin that experienced frequent flooding during the snowmelt season.

In the scenario with channels flowing half full (figure 4c), the stability values for bank failure were near the insipient point of failure. Results for bed scour were also near 1, but bank scour fell below the stable region with F.S. $<0.8$. Full-channel conditions pushed the F.S. for bank failure just into the unstable region $(<0.8)$ and greatly reduced F.S. for bank scour (figure $4 \mathrm{~d}$ ). These results are consistent with field observations that showed evidence of general channel instability with bank failures and bank and bed erosion evident as slumping banks and channel scour that exposed bridge pier footings along the study reaches. The bare banks scenario showed significant instability for the banks, with the F.S. well below 0.1 for full-channel flow (figure 4e).

Some variation of bank stability and bank scour between different cross sections was due to the geographic setting. In the lower reaches of the channel network, the drains are more channelized, while in the higher reaches the drains tend to follow the natural channel, have greater vegetative protection, and are not being actively dredged. The bank stability of the channelized sections was at the incipient point of failure, while the more natural channels were more stable.

Bed scour (incision) showed a similar trend in the half-full channel (figure 4c) scenario due to the topography of the Sebewaing watershed. The lower reaches of the drains had higher F.S. values for bed scour under bankfull flow conditions because of the more gentle terrain and thus lower channel slopes. Higher in the watershed, the terrain becomes more 


\section{Figure 4}

Stability results from applications of the CST: (a) Pre-dredged channel under bankfull flow, (b) Bankfull channel, post-dredging, (c) Half-full channels with ryegrass covered banks, (d) Full-channel flow with ryegrass covered banks, (e) Full-channel flow with bare banks, (f) Full-channel flow with shrub cover, (g) Full-channel flow with conifer tree cover, (h) Full-channel flow with deciduous tree cover.

a)

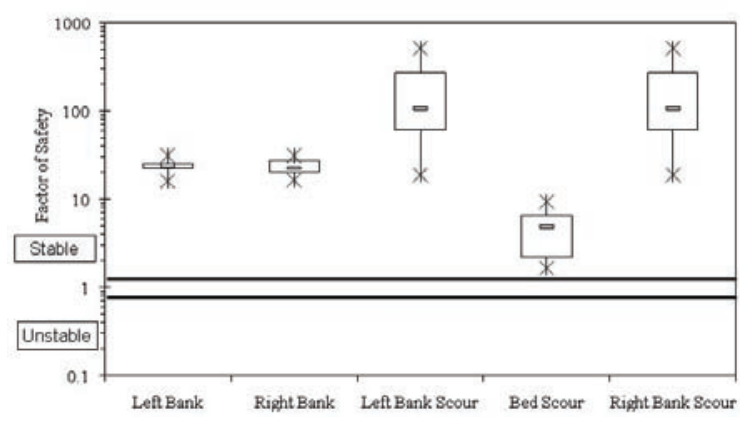

C)

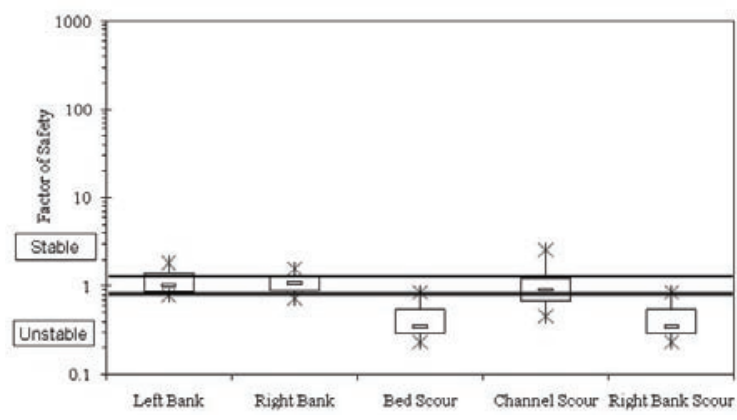

e)

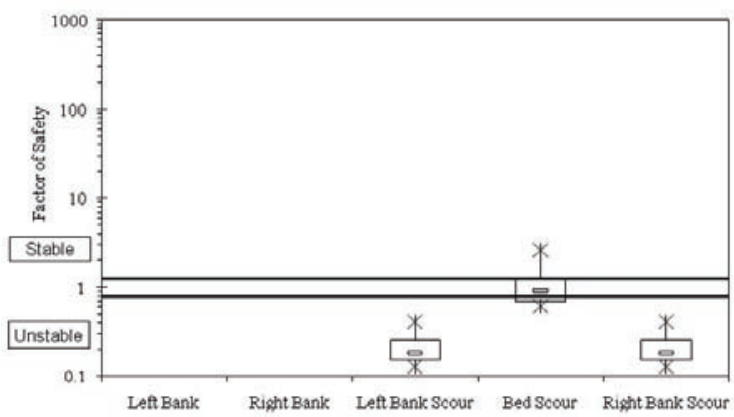

g)

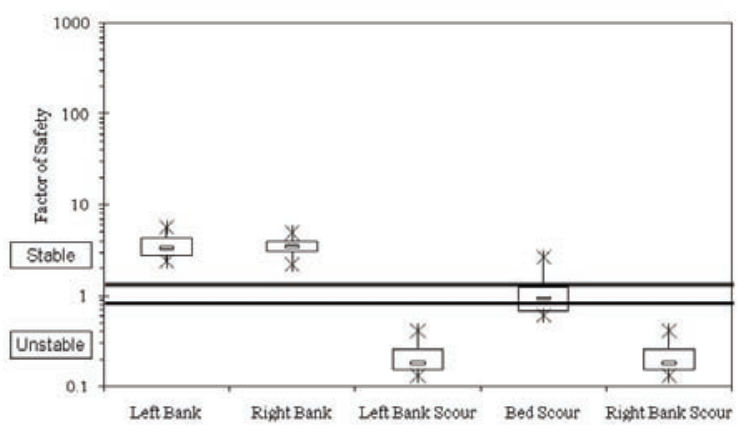

b)

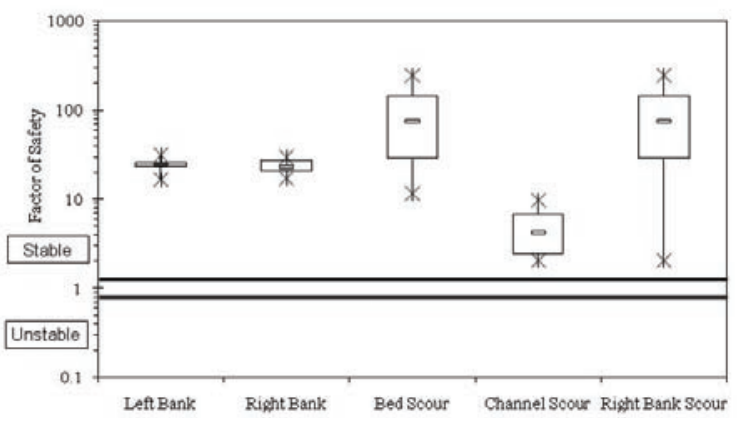

d)

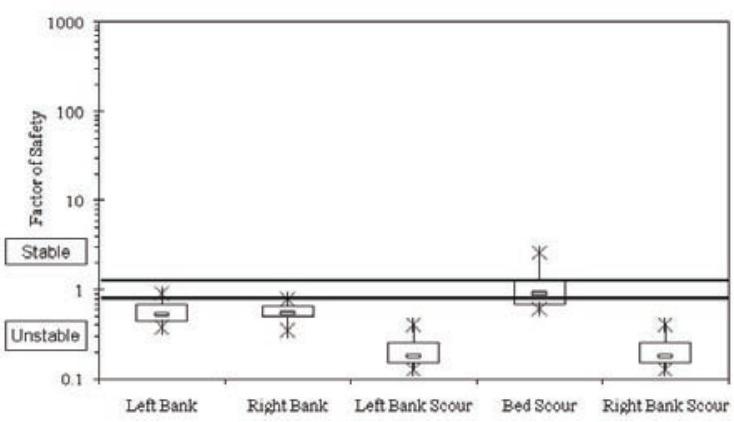

f)

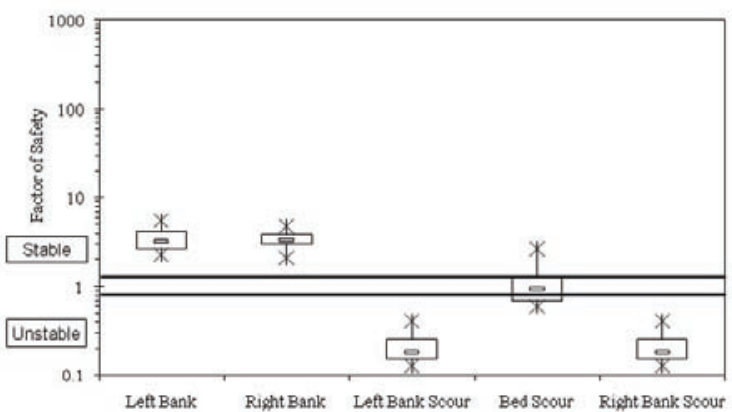

h)

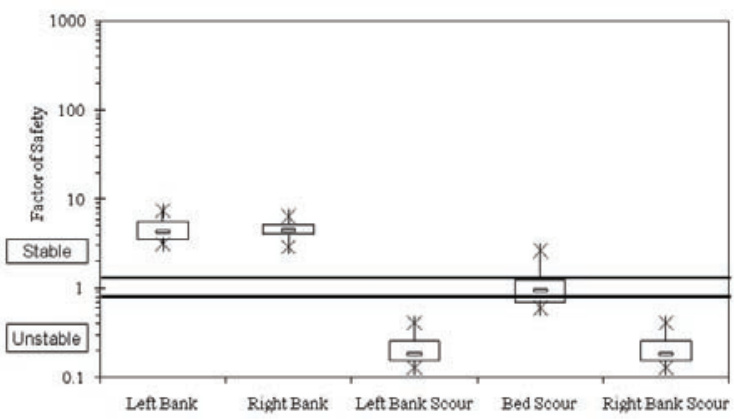


varied and channels have higher slopes, thus increasing the erosive power of the streams; F.S. for bed scour was significantly lower here-approximately one half the values observed in the lower portions of the watershed. With higher flow conditions typical during snowmelt runoff, all reaches were near or below the stability range for bed scour.

During full-channel flows, the CST indicated banks were unstable against bank failure even with ryegrass cover on the banks (figure 4d). These results reflect instability that was observed in the field. Figure 1 shows a typical cross section within the Sebewaing watershed that experiences high-flow periods during the spring snowmelt. Bank failure, bank scour, and bed scour were common along these reaches. No observations of bank stability, bank scour, and bed scour for shrubs and tree cover were available since most channels within the Sebewaing watershed were only grass covered.

The application of the CST with shrub and tree cover (figures $4 \mathrm{f}, 4 \mathrm{~g}$, and $4 \mathrm{~h}$ ) demonstrates the potential impact proper vegetation management within the riparian area near the banks can have on bank stability. With the addition of either local shrubs or trees, bank stability during and after the snowmelt season increased. The use of a $50 \%$ shrub- $50 \%$ ryegrass cover was predicted to increase bank stability six fold, on average, as compared to ryegrassonly covered banks. Results of the shrub cover application are shown in figure $4 \mathrm{f}$. Coniferous and deciduous forest covers (figures $4 \mathrm{~g}$ and $4 \mathrm{~h}$, respectively) resulted in very similar values to the shrub cover scenario, again showing significant increases in stability as compared to a ryegrass cover.

\section{SUMMARY AND CONCLUSIONS} Application of the CST within the Sebewaing watershed yielded results consistent with field observations. Ditch beds and banks were generally unstable during high-flow spring melting events; this would produce bank failure, such as slumping, as well as bed incision. Extreme high-flow events that occur during the spring snowmelt have been observed to cause bank and bed scour and bank failure around the Sebewaing watershed. The CST also revealed differences in stability that were due to changes in terrain and position within the watershed drainage network. When applied to watershed conditions, the CST can provide watershed managers and stakeholders with guidance for the selection of ditch management practices that will best facilitate the development of a stable drainage network and reduce fluvial sediment sources. The CST is applicable to rivers and streams located in the Great Lakes region and having lacustrine clay or till soils, making it useful for management decisions across the majority of the area.

The CST is undergoing additional development and testing in its current version to increase functionality and add requested features. Information regarding future availability and distribution of the CST may be obtained from the USACE Detroit District, Hydraulics and Hydrology Branch.

\section{ACKNOWLEDGEMENTS}

Funding for the original research and development of these datasets and computational methods was provided by the Marcell Experimental Forest, Northern Research Station, USDA Forest Service, and the Agricultural Experiment Station, University of Minnesota. Funding for further development, testing, and programming of the CST was provided by the USACE Detroit District. The authors extend their gratitude to Dr. Elon Verry, research hydrologist emeritus for the US Forest Service Northern Research Station, Grand Rapids, Minnesota, and Dr. Ken Brooks, professor at the Department of Forest Resources, University of Minnesota, St. Paul, Minnesota, for ongoing support and encouragement.

\section{REFERENCES}

Abernethy, B., and Rutherfurd, I. 2001. The distribution and strength of riparian tree roots in relation to riverbank reinforcement. Hydrological Processes 15(1):63-79.

Alabyan, A.M., and R.S. Chalov. 1998. Types of river patterns and their natural controls. Earth Surface Processes and Landforms 23(5):467-474.

ASCE (American Society of Civil Engineers). 1998. River width adjustment I: processes and mechanisms. Journal of Hydraulic Engineering 124(9):881-902.

Arulanandan, K., E. Gillogley, and R. Tully. 1980. Development of a quantities method to predict critical shear stress and rate of erosion of natu- ral undisturbed cohesive soils. Report GL-80-5. Vicksburg,MS: USACOE Waterways Experiment Station.

Bahnick, D.A., T.P. Markee, and R.K. Roubal. 1979 Chemical effects of red clays on western Lake Superior. US Environmental Protection Agency Report, EPA-905/9-79-003.

Chang, H.H. 1979. Minimum stream power and river channel patterns. Journal of Hydrology 41(3-4):303-327.

Charlton, F.G., P.M. Brown, and R.W. Benson. 1978. The hydraulic geometry of some gravel rivers in Britain. Hydraulics Research Station. IT 180.

Chow, V.T. 1959. Open Channel Hydraulics. New York: McGraw-Hill.

Darby, S.E.T., and C.R. Thorne. 1996. Development and testing of riverbank-stability analysis. Journal of Hydraulic Engineering 224(2):443-545.

Flintham, T.P., and P.A. Caring, P.A. 1988. The prediction of mean bed and wall boundary shear in uniform and compositely roughened channels. In Proceedings of the International Conference on River Regime, ed. W.P. White, 367-387. England: John Wiley \& Sons, Inc.

FTC\&H (Fishbeck, Thompson, Carr \& Huber, Inc.). 2001. Sebewaing River watershed management plan. Michigan: Huron and Tuscola Conservation Districts.

FTC\&H. 2004. Sebewaing River Watershed CMI project - Sebewaing Intercounty Drain best management practice design package. Michigan: Huron Conservation District.

Hickin, E.J. 1995. Hydraulic geometry and channel scour, Fraser River, British Columbia, Canada. In River Morphology, ed. Hickin, E.J. John Wiley \& Sons, Inc.

Huang,Y.R. 1983. Shear Strength. In Stability Analysis of Earth Slopes. New York, NY: Reinhold Publishing.

Huang, H.Q., and G.C. Nanson. 1998. The influence of bank strength on channel geometry: an integrated analysis of some observations. Earth Surface Process and Landforms 23(10):865-876.

Hupp, C.R. 1992. Riparian vegetation recovery patterns following stream channelization: a geomorphic perspective. Ecology 73(4):1209-1226.

Hupp, C.R. 1999. Relations among riparian vegetation, channel incision processes and forms, and large woody debris. In Incised River Channels, Processes, Forms, Engineering and Management, eds. S.E. Darby and A. Simon. John Wiley \& Sons, Inc.

Kapustka, L.A., and D.W. Davidson. 1979. Role of Plant Roots in Red Clay Erosion. Impact of Nonpoint Pollution Control on Western Lake 
Superior, Red Clay Project Final Report Part II. US Environmental Protection Agency Report, EPA 905/9-76-002-B.

Knight, D.W., J.D. Demetrious, and M.E. Hamed, 1984. Boundary shear in smooth rectangular channels. Journal of Hydraulic Engineering 11(4):405-422.

Leopold, L.B., M.G. Wolman, and J.P. Miller. 1992. Fluvial processes in geomorphology. Dover Publications.

Millar, R.G. 2000. Influence of bank vegetation on alluvial channel patterns. Water Resources Research 36(4):1109-1118.

Millar, R.G., and M.C. Quick. 1998. Stable width and depth of gravel-bed rivers with cohesive banks. Journal of Hydraulic Engineering 124(10):1005-1013.

Osman, A.M., and C.R. Thorne. 1988. Riverbank stability analysis. I: theory. Journal of Hydraulic Engineering, 114(2):134-150.

Riedel, M.S., K.N. Brooks, and E.S. Verry. 2005. Impacts of land use conversion on bankfull discharge and mass wasting.Journal of Environmental Management 76(4):326-337.

Riedel, M.S., K.N. Brooks, and E.S. Verry. 2006. Stream bank stability assessment in grazed riparian areas. In Proceedings of the Joint 8th Federal Interagency Sedimentation and 3rd Hydrologic Modeling Conferences, Reno, NV.

Riedel, M.S., E.S.Verry, and K.N. Brooks. 2002. Land use impacts on fluvial processes in the Nemadji Watershed. Hydrological Science and Technology 18(1-4): 197-205.

Ritter, D.F., R.C. Kochel, and J.R. Miller. 1995. Fluvial Processes. In Process Geomorphology, 3rd edition, Chapter 6. Dubuque, IA: Wm.C. Brown Publishers.

Schumm, S.A. 1960. The shape of alluvial rivers in relation to sediment type. USGS Professional Paper 352-B.

Schwartz, C. 2006. Sebewaing River Intercounty Drain - an odyssey in watershed management. Pipeline 15(2):20-25.

Soller, D.R., and P.H. Packard. 1998. Digital representation of a map showing the thickness and character of Quaternary sediments in the glaciated United States east of the Rocky Mountains. US Geological Survey Digital Data Series DDS38. http://pubs.usgs.gov/dds/dds38/shape.html.

Taylor, D.W. 1948. Fundamentals of Soil Mechanics. New York: John Wiley \& Sons, Inc.

USACE (US Army Corps of Engineers). 2007. Sebewaing River sediment transport modeling study. Prepared for USACE Detroit District by W.F. Baird and Associates, Ltd.
USDA. 2004. Conservation Reserve Program enrollment statistics and program information 2004 fiscal year. US Dept of Agriculture Farm Service Agency Report.

Williams, Osminski, \& Associates. 2002. State and Cooling county drain, Columbia, Almer, and Ellington townships, Tuscola County, Michigan. Surveys conducted December, 1998 - March 2000.

Wu, T.U. 1976. Investigation of landslides on Prince of Wales Island, Alaska. Geotechnical Report No. 5. Columbus, OH: Department of Civil Engineering, Ohio State University. 